\title{
Reduction of Postfire Properties of High-Strength Concrete
}

\author{
Neno Torić, Ivica Boko, and Bernardin Peroš \\ University of Split, Faculty of Civil Engineering, Architecture and Geodesy, Matice Hrvatske 15, 21000 Split, Croatia \\ Correspondence should be addressed to Neno Torić; neno.toric@gradst.hr
}

Received 1 October 2012; Revised 3 February 2013; Accepted 5 February 2013

Academic Editor: Luigi Nicolais

Copyright (C) 2013 Neno Torić et al. This is an open access article distributed under the Creative Commons Attribution License, which permits unrestricted use, distribution, and reproduction in any medium, provided the original work is properly cited.

\begin{abstract}
This paper presents an experimental study of behaviour of high-strength concrete at high temperature. Reduction of the mechanical properties of concrete was determined starting from the period when the concrete specimens were heated to the maximum temperature and cooled down to ambient temperature and the additional 96 hours after the initial cooling of the specimens. The study includes determination of compressive strength, dynamic and secant modulus of elasticity, and stress-strain curves of concrete specimens when exposed to temperature level up to $600^{\circ} \mathrm{C}$. The study results were compared with those obtained from other studies, EN 1994-1-2 and EN 1992-1-2. Tests point to the fact that compressive strength of concrete continues to reduce rapidly 96 hours after cooling of the specimens to ambient temperature; therefore indicating that the mechanical properties of concrete have substantial reduction after being exposed to high temperature. The study of the dynamic and secant modulus of elasticity shows that both of the properties are reduced but remain constant during the period of 96 hours after cooling. The level of postfire reduction of compressive strength of the analyzed concrete is substantial and could significantly affect the postfire load bearing capacity of a structure.
\end{abstract}

\section{Introduction}

Mechanical properties of concrete exposed to high temperature represent the basic parameters for modelling the behaviour of concrete structures during and after fire exposure. Two types of mechanical properties are used for modelling: hot and residual properties. Hot properties are obtained when the specimen is heated to the maximum temperature, while the residual properties are obtained when the specimen is cooled down to ambient temperature. Generally, there are two great families available in civil engineering practice today: normal-strength concrete (NSC) and highstrength concrete (HSC). The current scientific research has shown that the reduction of mechanical properties of HSC can be different from that of NSC due to lower fire endurance of HSC $[1,2]$. It is considered by the engineering building codes that the concrete classified as HSC has a minimum value of compressive strength of $65 \mathrm{MPa}$ after 28 days (determined on concrete cube specimens). Due to chemical and physical processes (e.g., formation of calcium hydroxide from lime with volume expansion) that occur after the heating of concrete $[3,4]$, residual properties show a tendency for further reduction with respect to time after cooling. Time reduction process (strength loss and recovery) is in general almost fully reversible for NSC $[5,6]$. However, analyses of different concrete mixes have demonstrated that the reduction process varies significantly with respect to the total time required for the reduction process to finish. Variation is especially apparent for the total time required to reach the minimum of residual strength (2-8 weeks for compressive strength [5]).

The majority of current researches have been focused on the reduction of hot and residual compressive strength of concrete, which represents the most important parameter in modelling of structural behaviour $[1,4,5]$. Still, there is a small number of researchs involving the reduction of secant and dynamic modulus of elasticity of concrete after fire exposure. Furthermore, the impact of time reduction process on compressive strength and residual stress-strain curves after fire exposure has not been explicitly considered in the current scientific research [7-9]. Although the phenomenon of strength reduction of concrete after exposure to high temperature has been observed for some time, no special attention has been given to it by the engineering building codes, that is, EN 1994-1-2 and EN 1992-1-2. It is necessary to determine the magnitude of the postfire reduction of 
TABle 1: Mix design of the investigated concrete.

\begin{tabular}{lc}
\hline $1 \mathrm{~m}^{3}$ & \\
\hline CEM I 42.5 R $\left(\mathrm{kg} / \mathrm{m}^{3}\right)$ & 425 \\
Water $\left(\mathrm{L} / \mathrm{m}^{3}\right)$ & 141 \\
$\mathrm{w} / \mathrm{c}$ & 0.33 \\
Plasticizer $\left(\mathrm{L} / \mathrm{m}^{3}\right)$ & 4.25 \\
Fine aggregate $0-4 \mathrm{~mm}\left(\mathrm{~kg} / \mathrm{m}^{3}\right)$ & 1510 \\
Coarse aggregate $4-8 \mathrm{~mm}\left(\mathrm{~kg} / \mathrm{m}^{3}\right)$ & 265 \\
Slump & Earth dry \\
Compressive strength at 28 days-cube $(\mathrm{MPa})$ & $72.4 \pm 1.98$ \\
\hline
\end{tabular}

mechanical properties of concrete in order to estimate the level of impact on the structural load bearing capacity after fire exposure.

This study is focused on the short-term reduction of residual mechanical properties of concrete mix specific for the production of hollow core prestressed concrete slabs. This mix is specific because of the low slump (i.e., earth dry consistency) which is essential for the production process of hollow core slabs. Given the fact that the analyzed concrete is of a low slump, it can be utilized only in the production of hollow core slabs, but not in the construction of common concrete buildings. In addition, the concrete mix has a low $\mathrm{w} / \mathrm{c}$ ratio (0.33); thus, its compressive strength is relatively high (average $72 \mathrm{MPa}$ on concrete cube specimens after 28 days). This value of compressive strength classifies the concrete mix as a high-strength concrete; however, the shape of the reduction curve for the compressive strength suggests that it has a reduction trend similar to NSC. The literature review that has been covered in this paper reveales that most of HSC mixes have a higher-strength reduction than NSC mixes making the analyzed concrete mix interesting for the scientific research. Short-term reduction includes assessment of residual properties in time intervals up to 96 hours after initial cooling, with an additional comparison of residual compressive strength and stress-strain curves with hot compressive strength and hot stress-strain curves.

\section{Experimental Programme}

Experimental programme included determination of the following concrete properties up to $600^{\circ} \mathrm{C}$ :

(i) hot and residual compressive strength,

(ii) residual secant and dynamic modulus of elasticity,

(iii) hot and residual stress-strain curves.

2.1. Concrete Mix and Specimen Preparation. The proportions of the investigated concrete mix are indicated in Table 1. The binder included ordinary portland cement CEM I 42.5 $\mathrm{R}$. In order to achieve satisfactory workability of concrete for production of hollow core slabs, plasticizer based on polycarboxylic ether polymers marked as "RHEOFIT 700" was used. Coarse and fine aggregates were comprised of a crushed limestone aggregate with a diameter smaller than $8 \mathrm{~mm}$ and continuous grading.
The concrete specimens prepared were cylinders with dimensions of $\phi 75 / 225 \mathrm{~mm}$. All specimens were demoulded 1 day after casting and were kept at a temperature of $20 \pm$ $3^{\circ} \mathrm{C}$ and a relative humidity of $95 \%$ in a curing room for 6 days. Subsequently, the specimens were moved to an air temperature of $20 \pm 3^{\circ} \mathrm{C}$ and relative humidity of $50 \%$ until testing. The testing programme was initiated when the specimens were 5 months of age. In order to avoid explosive spalling of tested concrete, all specimens had been dried until a constant mass was achieved at a temperature of $105 \pm 5^{\circ} \mathrm{C}$ and after that were kept in desiccator until testing.

\subsection{Testing Procedure}

2.2.1. Specimen Temperature Cycle. Testing procedure for determining hot and residual compressive strength and residual secant modulus of elasticity was adopted from the recommendations of the RILEM Technical Committee TC$129[10,11]$. The specimens were subjected to four different temperature cycles up to $200,400,500$, and $600^{\circ} \mathrm{C}$ in an electrical furnace. For each temperature cycle, four cylindrical specimens were used (Figure 1). One specimen was equipped with three $\mathrm{NiCr}$ thermocouples for monitoring temperature evolution inside the specimen, while the other three served for determination of investigated concrete property.

The first part of the temperature cycle consisted of heating at $1-2.5^{\circ} \mathrm{C} / \mathrm{min}$ up to a target temperature. After reaching the target temperature, it was kept constant for 1 hour in order to ensure steady-state thermal condition throughout the specimens (Figure 1). The last part of the cycle consisted of slow cooling down to ambient temperature in order to avoid thermal shock. The specimens were tested while being hot, immediately after having been cooled down to ambient temperature and 48 and 96 hours after the initial cooling. Figure 2 presents the heating-cooling cycle of the specimens used for determining residual compressive strength.

In order to ensure the minimal testing time during the hot compressive strength test, the furnace was placed near the testing machine. Maximal testing time, comprised of the time necessary for the extraction of the specimens from furnace, placing them in the testing machine, and the specimen loading time, was less than 3 minutes. Minimization of the testing time for hot compressive strength was necessary in order to avoid extra damage in the end regions of the specimen [12].

2.2.2. Specimen Loading Cycle. Hot and residual concrete properties were determined as the mean value of the three tests per each target temperature. The compressive strength, the secant modulus of elasticity, and the stress-strain curves were obtained using hydraulic Toni Technik testing machine (Figure 3) with $3000 \mathrm{kN}$ capacity and speed of applied load of $0.5 \mathrm{MPa} / \mathrm{s}$. The stress-strain curves were obtained by measuring the load increment and the increment of relative displacement of the machine's press platens. Relative displacement of the press platens was measured with the LVDT device that was attached to the machine. 


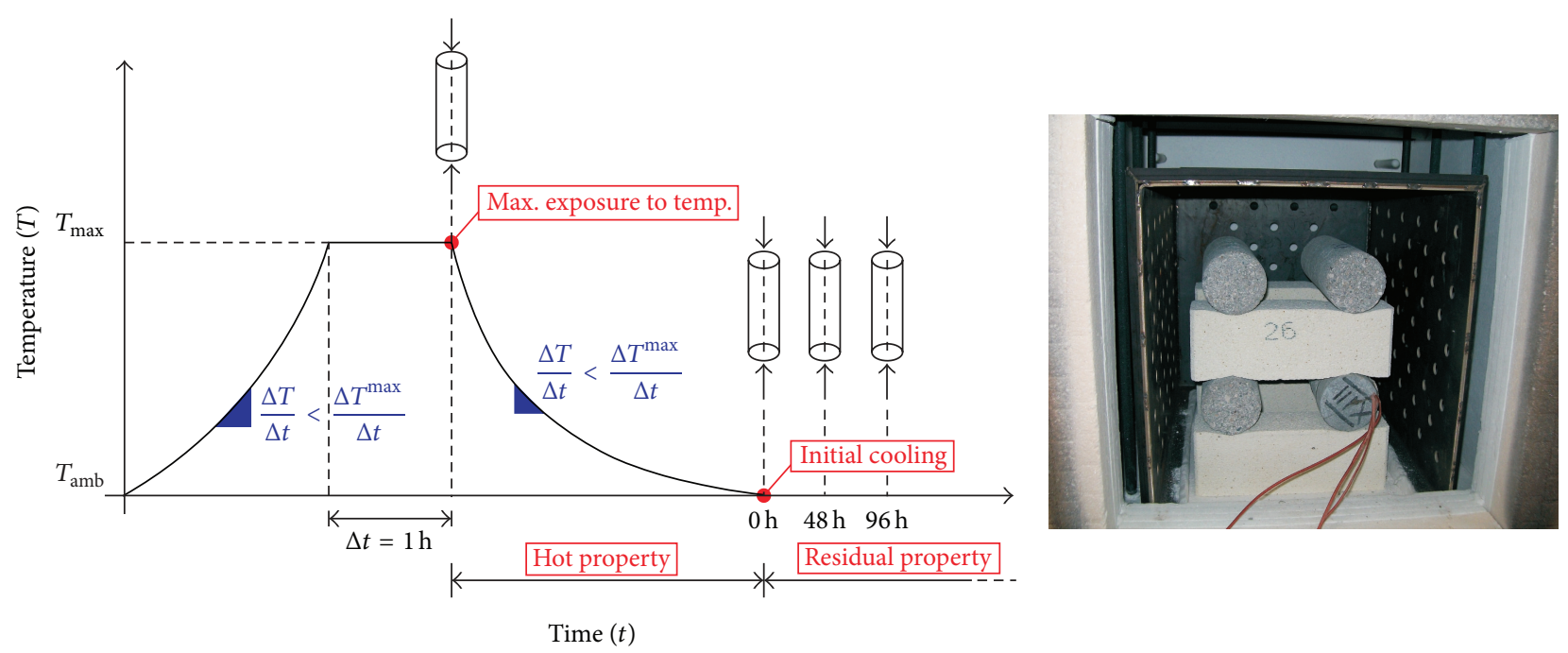

FIGURE 1: Heating cycle for concrete specimens and furnace setup.

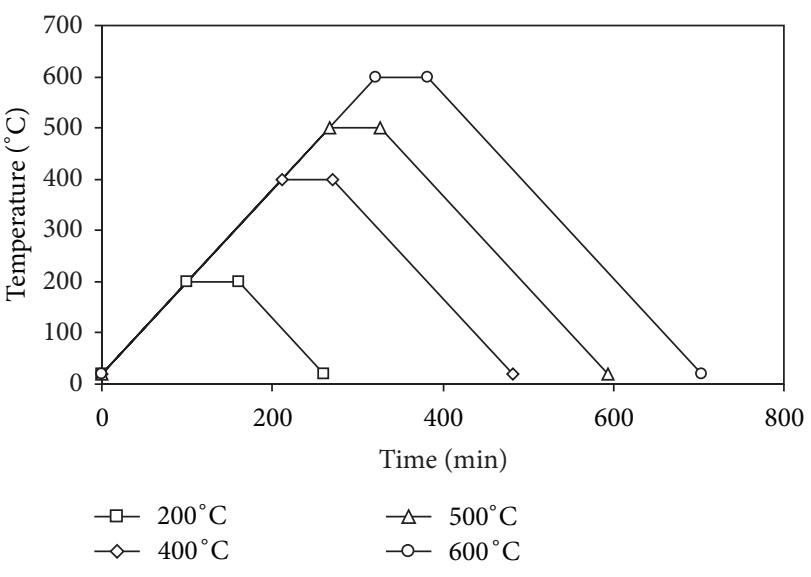

FIGURE 2: Heating-cooling cycle of the specimens for determining residual compressive strength.

2.2.3. Secant Modulus of Elasticity. Secant modulus of elasticity of concrete was calculated after applying load sequence on specimen that is presented in Figure 3 and by using the following expression:

$$
E_{s c, T}=\frac{\Delta \sigma}{\Delta \varepsilon}
$$

where $\Delta \sigma=0.15 f_{c, T}, \Delta \varepsilon=\left.\varepsilon\right|_{0.3 f_{c, T}}-\left.\varepsilon\right|_{0.15 f_{c, T}}$, and $f_{c, T}$ is the compressive strength of concrete specimen at temperature level $T(\mathrm{MPa})$.

Strain increment $\Delta \varepsilon$ was determined as the mean value of measurements that were obtained with two extensometers (Figure 3).

2.2.4. Dynamic Modulus of Elasticity. Dynamic modulus of elasticity was obtained by ultrasonic pulse velocity measurement using a commercial device made by Proceq Company (Figure 4). Dynamic modulus of elasticity of concrete was determined by releasing ultrasonic pulse through concrete specimen. By calculating the speed of ultrasonic pulse in the specimen, dynamic modulus was calculated from the following equation:

$$
E_{c, T}=\frac{v^{2} \rho\left(1+\mu_{d}\right)\left(1-2 \mu_{d}\right)}{\left(1-\mu_{d}\right)},
$$

where $v$ is the speed of ultrasonic pulse in the specimen $(\mathrm{m} / \mathrm{s})$, $\rho$ is the density of concrete $\left(\mathrm{kg} / \mathrm{m}^{3}\right)$, and $\mu_{d}$ is the Poisson coefficient $(=0.2)$.

2.2.5. Preloading of Specimens. In order to test the effect of short-term preloading on stress-strain curves after fire exposure, some tested concrete specimens were preloaded. Before the stress-strain curves were determined, specimens had been preloaded using a load sequence that is essentially used for determining secant modulus of elasticity (Figure 3). After the preloading sequence had been inflicted, the stressstrain curves of the specimens were determined.

\section{Study Results and Discussion}

The following chapter presents the results of the conducted experimental study as well as a comparison to other studies of HSC and NSC [13-21] that have comparable parameters with the studied concrete mix (water/cement ratio, aggregate composition, and developed compressive strength). Tables 2 , 3 , and 4 display the study results of hot properties and residual properties of concrete after cooling to ambient temperature ( 0 and $96 \mathrm{~h}$ ) without the preloading of specimens. Results for concrete specimens that were not preloaded by loading sequence presented in Figure 3 are marked with letter a, and the results of preloaded specimens are marked with letter $b$.

Figures 5 and 6 present the comparison of results between the experimental study and the various studies of HSC and NSC for compressive strength of concrete. Hot compressive strength was determined at the time when the specimens had 

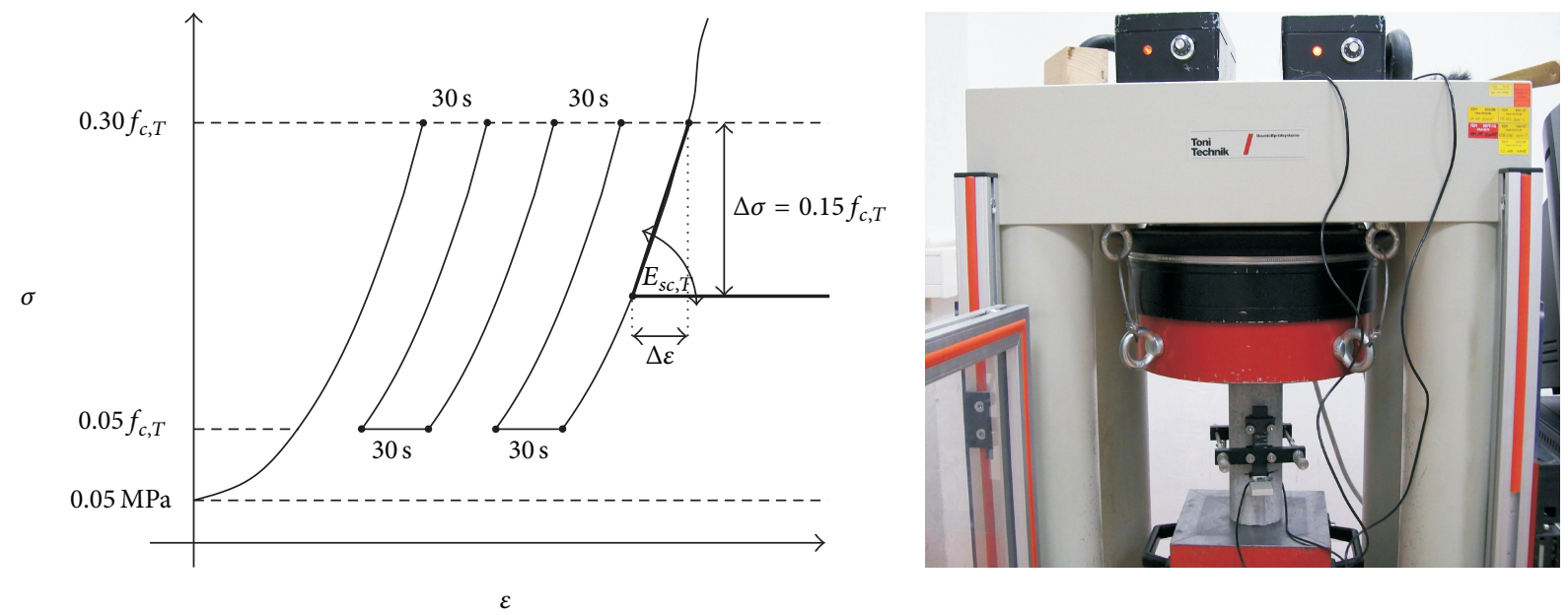

FIGURE 3: Experimental procedure for calculating secant modulus of elasticity [10] and the testing machine.

TABLE 2: Hot compressive strength of concrete specimens while heated to a predetermined temperature level—(a).

\begin{tabular}{|c|c|c|c|c|c|c|c|c|c|c|}
\hline \multirow{2}{*}{ Property } & \multicolumn{10}{|c|}{ Temperature level $\left({ }^{\circ} \mathrm{C}\right)$} \\
\hline & \multicolumn{2}{|c|}{20} & \multicolumn{2}{|c|}{200} & \multicolumn{2}{|c|}{400} & \multicolumn{2}{|c|}{500} & \multicolumn{2}{|c|}{600} \\
\hline \multirow{3}{*}{$f_{c, T}(\mathrm{MPa})$} & 63.6 & & 65.8 & & 51.5 & & 38.7 & 27.7 & & \\
\hline & 61.8 & $\begin{array}{c}\text { Mean } \\
62.2\end{array}$ & 58.8 & $\begin{array}{c}\text { Mean } \\
62.2\end{array}$ & 47.0 & $\begin{array}{c}\text { Mean } \\
50.0\end{array}$ & 39.9 & $\begin{array}{c}\text { Mean } \\
39.9\end{array}$ & 32.3 & $\begin{array}{c}\text { Mean } \\
29.0\end{array}$ \\
\hline & 61.3 & & 61.9 & & 51.4 & & 41.1 & & 26.9 & \\
\hline
\end{tabular}

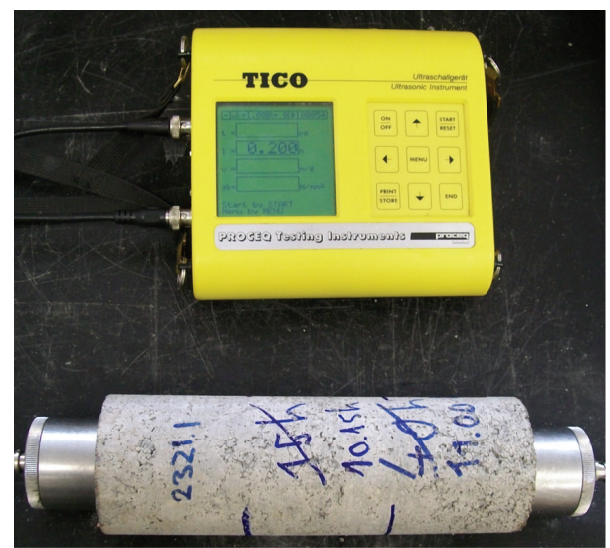

FIGURE 4: Ultrasonic pulse measuring device.

the maximum temperature exposure. Residual compressive strength $f_{c, T}$ was determined after the initial cooling of specimens $(0 \mathrm{~h})$, after 48 and 96 hours. The results were normalized with respect to cold strength $f_{c, 20}$ (strength before exposure to high temperature).

Comparing the results between reduction coefficients for hot and residual compressive strength at initial cooling $(0 \mathrm{~h})$, a negligible difference was observed indicating that there had been virtually no reduction of compressive strength from the time period when the specimen was heated to a maximum temperature to the time period when the specimen was cooled to ambient temperature (Figure 5). This effect was

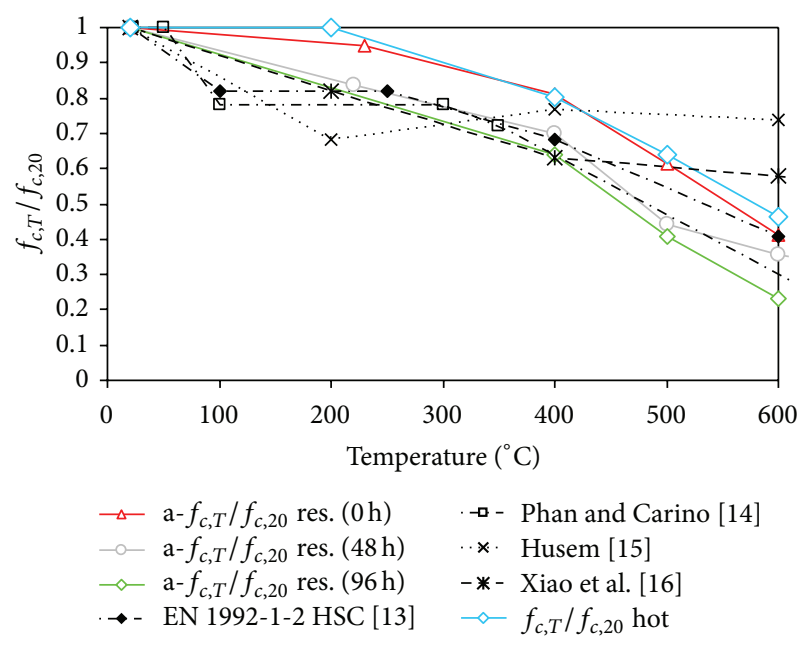

FIGURE 5: Reduction of compressive strength $f_{c, T}$-study results and comparison with different studies of HSC.

ascribed to a slow thermal cooling gradient of the specimens in the furnace [5]. Furthermore, a substantial reduction of compressive strength was observed 96 hours after the initial cooling, declining for approximately $20 \%$ of the value measured in the initial cooling phase. Figure 5 shows that the trend of reduction of the studied concrete is similar to the trend of reduction observed for NSC. It is clearly evident that the reduction coefficients for compressive strength proposed by engineering building codes $[13,17]$ are on the unsafe side 
TABLE 3: Residual properties of concrete specimens after cooling to ambient temperature $(0 \mathrm{~h})-(\mathrm{a})$.

\begin{tabular}{|c|c|c|c|c|c|c|c|c|c|c|}
\hline \multirow{2}{*}{ Property } & \multicolumn{10}{|c|}{ Temperature level $\left({ }^{\circ} \mathrm{C}\right)$} \\
\hline & \multicolumn{2}{|c|}{20} & \multicolumn{2}{|c|}{230} & \multicolumn{2}{|c|}{400} & \multicolumn{2}{|c|}{500} & \multicolumn{2}{|c|}{600} \\
\hline \multirow{3}{*}{$f_{c, T}(\mathrm{MPa})$} & 57.6 & & 63.1 & & 51.9 & & 38.6 & & 25.4 & \\
\hline & 65.7 & $\begin{array}{c}\text { Mean } \\
63.6\end{array}$ & 57.6 & $\begin{array}{c}\text { Mean } \\
60.4\end{array}$ & 49.9 & $\begin{array}{c}\text { Mean } \\
51.6\end{array}$ & 38.1 & $\begin{array}{c}\text { Mean } \\
39.1\end{array}$ & 27.9 & $\begin{array}{c}\text { Mean } \\
26.3\end{array}$ \\
\hline & 67.6 & & 60.6 & & 53.0 & & 40.6 & & 25.5 & \\
\hline \multirow{3}{*}{$E_{s c, T}(\mathrm{MPa})$} & 37694 & & 30365 & & 18244 & & 13430 & & 10078 & \\
\hline & 37098 & $\begin{array}{l}\text { Mean } \\
38159\end{array}$ & 26214 & $\begin{array}{l}\text { Mean } \\
28463\end{array}$ & 16876 & $\begin{array}{l}\text { Mean } \\
17570\end{array}$ & 11508 & $\begin{array}{l}\text { Mean } \\
12624\end{array}$ & 11377 & $\begin{array}{l}\text { Mean } \\
10289\end{array}$ \\
\hline & 39684 & & 28809 & & 17589 & & 12932 & & 9413 & \\
\hline \multirow{3}{*}{$E_{c, T}(\mathrm{MPa})$} & 41056 & & 33925 & & 18055 & & 13173 & & 12259 & \\
\hline & 45484 & $\begin{array}{l}\text { Mean } \\
44127\end{array}$ & 29166 & $\begin{array}{l}\text { Mean } \\
32258\end{array}$ & 16255 & $\begin{array}{l}\text { Mean } \\
16955\end{array}$ & 11232 & $\begin{array}{l}\text { Mean } \\
12332\end{array}$ & 13295 & $\begin{array}{l}\text { Mean } \\
12599\end{array}$ \\
\hline & 45842 & & 33681 & & 16555 & & 12592 & & 12244 & \\
\hline
\end{tabular}

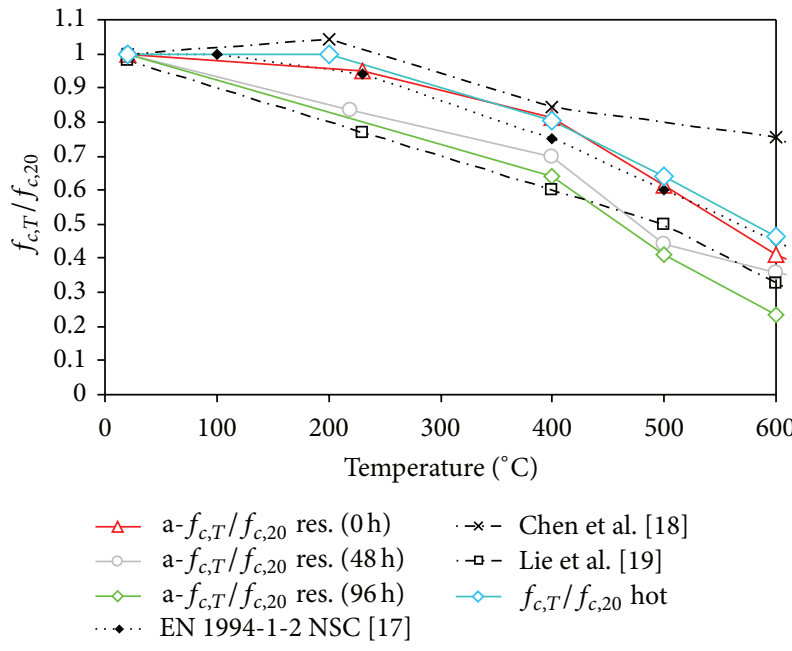

FIGURE 6: Reduction of compressive strength $f_{c, T}$-study results and comparison with different studies of NSC.

regarding the observed short-time reduction effect. Due to the magnitude and time dependency of short-term reduction of compressive strength, postfire load bearing capacity of structure is reduced over time after fire exposure. In turn, this may lead to structure failure.

Figures 7 and 8 present the results of the experimental study and comparison with similar studies of HSC and NSC for secant and dynamic modulus of elasticity of concrete. Dynamic modulus is generally considered to be equivalent to tangent modulus of elasticity [22]. Large discrepancy exists between the study results and the values obtained from the stress-strain curves taken from $[13,17]$. This is mainly because the stress-strain curves from Eurocode implicitly account for the additional strains that occur during the first heating of concrete, namely, transient creep strain [23].

Short-term reduction, for both of the dynamic and secant modulus is almost negligible during the period of 96 hours after the initial cooling. This finding contributes to the fact

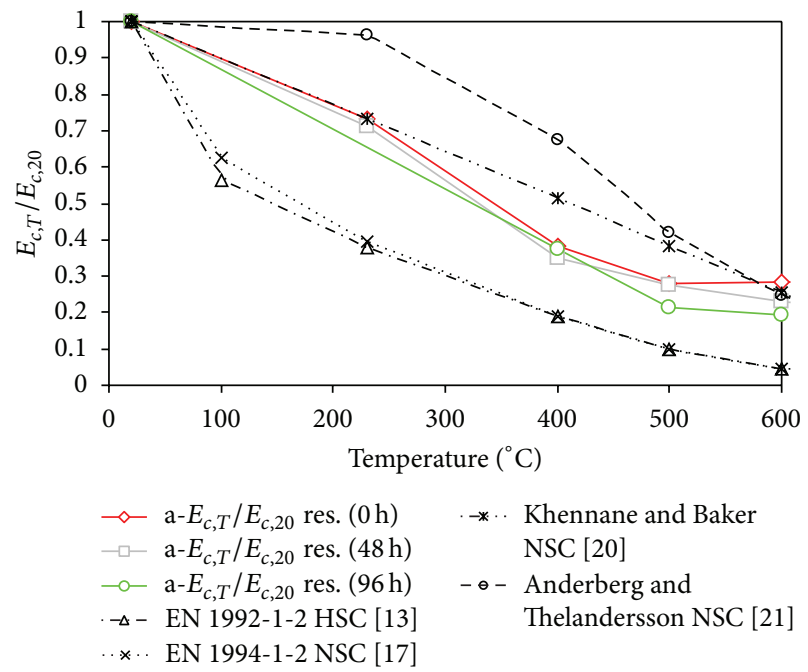

FIGURE 7: Reduction of dynamic modulus $E_{c, T}$-comparison with different studies of NSC and HSC.

that chemical and physical processes that occur after the initial cooling only affect the compressive strength, while the reduction of modulus of elasticity depends solely on the temperature level that is used to heat the concrete. Different short-term losses in residual conditions between the compressive strength and secant modulus suggest that chemical and physical processes happening after the initial cooling are more pronounced if the specimen is exposed to a higher stress level.

Figures 9-11 present the comparison between hot and residual stress-strain curves. Figure 9 shows a slight difference between the hot stress-strain curves and the residual stress-strain curves determined on specimens without preloading. The slope of the two types of stress-strain curves is quite similar, with hot specimens having somewhat a higher value of the initial tangent modulus of elasticity. Furthermore, an additional difference regarding the value of peak strain is noticeable. Namely, the hot specimens show a lower value 
TABLE 4: Residual properties of concrete specimens after cooling to ambient temperature ( $96 \mathrm{~h})$ - (a).

\begin{tabular}{|c|c|c|c|c|c|c|c|c|}
\hline \multirow{2}{*}{ Property } & \multicolumn{8}{|c|}{ Temperature level $\left({ }^{\circ} \mathrm{C}\right)$} \\
\hline & \multicolumn{2}{|c|}{230} & \multicolumn{2}{|c|}{400} & \multicolumn{2}{|c|}{500} & \multicolumn{2}{|c|}{600} \\
\hline \multirow{3}{*}{$f_{c, T}(\mathrm{MPa})$} & 54.6 & & 42.5 & & 30.4 & & 17.0 & \\
\hline & 57.2 & $\begin{array}{c}\text { Mean } \\
54.5\end{array}$ & 41.9 & $\begin{array}{c}\text { Mean } \\
43.0\end{array}$ & 26.9 & $\begin{array}{c}\text { Mean } \\
27.6\end{array}$ & 15.6 & $\begin{array}{c}\text { Mean } \\
17.4\end{array}$ \\
\hline & 51.7 & & 44.7 & & 25.5 & & 19.6 & \\
\hline \multirow{3}{*}{$E_{s c, T}(\mathrm{MPa})$} & 30205 & & 17057 & & 10892 & & 6639 & \\
\hline & 25834 & $\begin{array}{l}\text { Mean } \\
28309\end{array}$ & 16788 & $\begin{array}{l}\text { Mean } \\
16886\end{array}$ & 10646 & $\begin{array}{l}\text { Mean } \\
10393\end{array}$ & 6227 & $\begin{array}{r}\text { Mean } \\
6406\end{array}$ \\
\hline & 28889 & & 16814 & & 9642 & & 6352 & \\
\hline \multirow{3}{*}{$E_{c, T}(\mathrm{MPa})$} & 31745 & & 16362 & & 11091 & & 6752 & \\
\hline & 28254 & $\begin{array}{l}\text { Mean } \\
29206\end{array}$ & 16410 & $\begin{array}{l}\text { Mean } \\
16463\end{array}$ & 8401 & $\begin{array}{c}\text { Mean } \\
9489\end{array}$ & 10363 & $\begin{array}{c}\text { Mean } \\
8337\end{array}$ \\
\hline & 27619 & & 16616 & & 8975 & & 7896 & \\
\hline
\end{tabular}

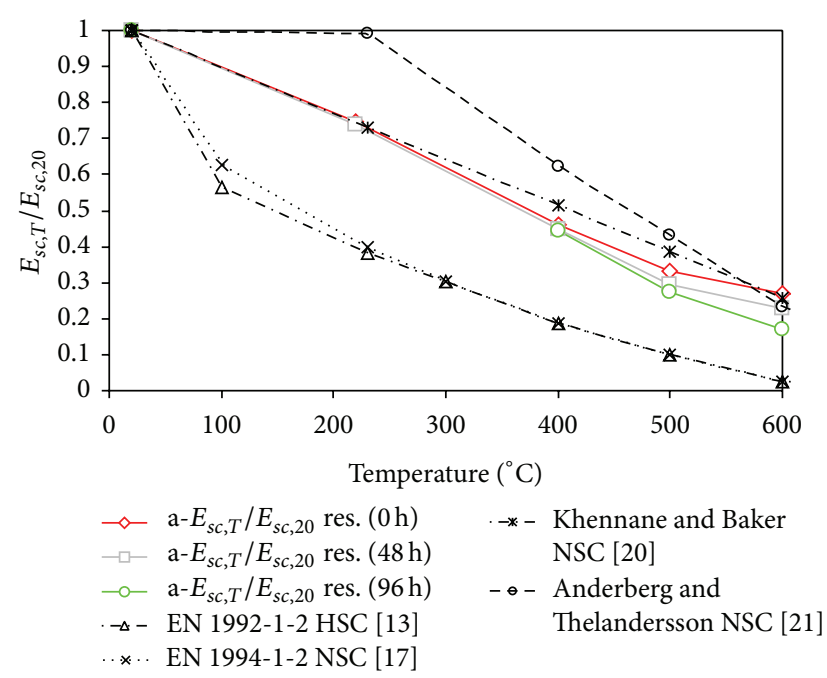

FIGURE 8: Reduction of secant modulus $E_{s c, T}$-comparison with different studies of NSC and HSC.

of peak strain in comparison with the values of peak strain obtained from the specimens tested after cooling to ambient temperature. The smaller value of peak strain obtained from hot specimens points to a more brittle behaviour of concrete while heated to maximum temperature.

It should be noted that beside the lower values of peak stress and strain, the difference between the hot and the residual stress-strain curves is rather limited. This is due to the short-time period between the time at which the specimen was initially cooled and the time of the residual test (0-96 hours).

Comparing the a and $\mathrm{b}$ stress-strain curves of specimens tested at ambient temperature from Figure 11, it can be observed that preloading of specimens has a greater influence only on peak strain but a less influence on the value of compressive strength (Figure 10). This effect is approximately valid for the testing of specimens at high temperature as well [21]. Additionally, preloading does not have any higher

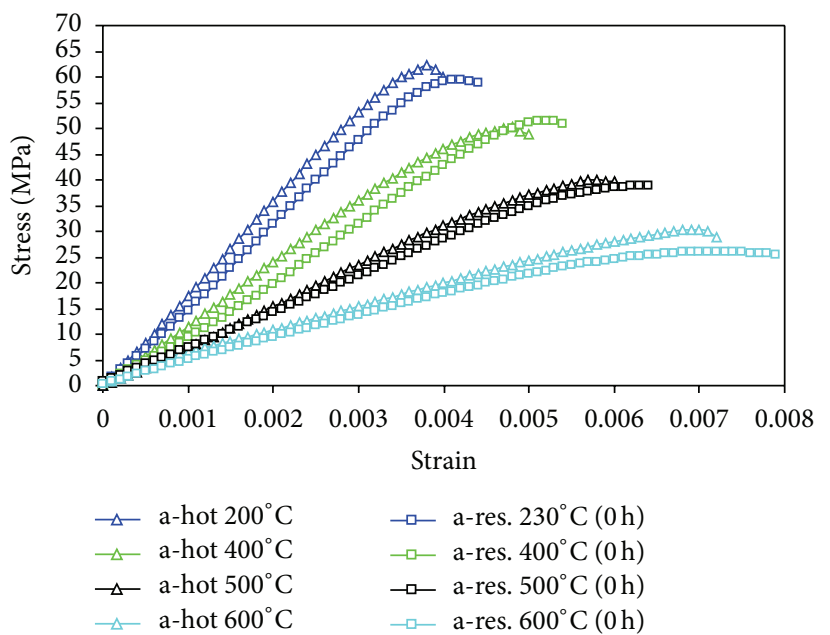

FIGURE 9: Comparison between hot stress-strain curves and residual stress-strain curves $(0 \mathrm{~h})$.

impact on the value of compressive strength because of the low level of the applied stress (5-30\% of compressive strength). Consequently, the load damage applied to concrete specimens has a dominant influence only on the tangent modulus of elasticity. Additional stress-strain curves obtained from preloaded specimens tested 48 and 96 hours after the initial cooling (Figure 11) show gradual decrease of peak strain at the maximum stress accompanied with the increase of initial modulus of elasticity, which are effects happening solely due to preloading of specimens. Figure 11 also informs us that the effects caused by preloading of specimens slowly diminish with the increase of the level of thermal exposure. In combination with the gradual decrease of residual compressive strength with respect to time after initial cooling, residual stress-strain curves show that the postfire residual curves are time dependent and point to a more brittle behaviour of preloaded concrete specimens after fire exposure. 


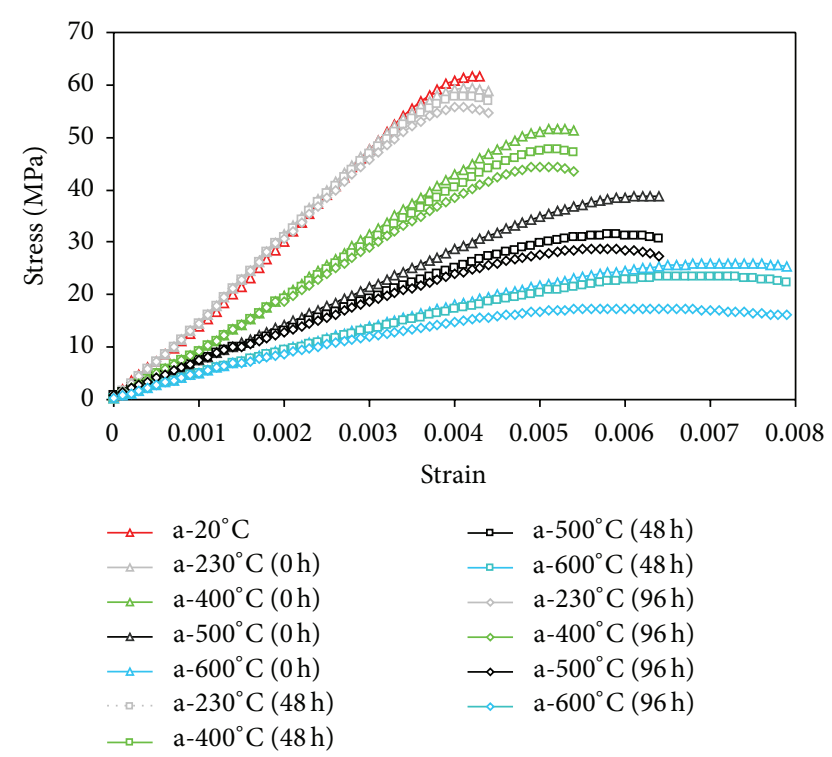

FIGURE 10: Comparison between residual stress-strain curves obtained after initial cooling-without specimen preloading.

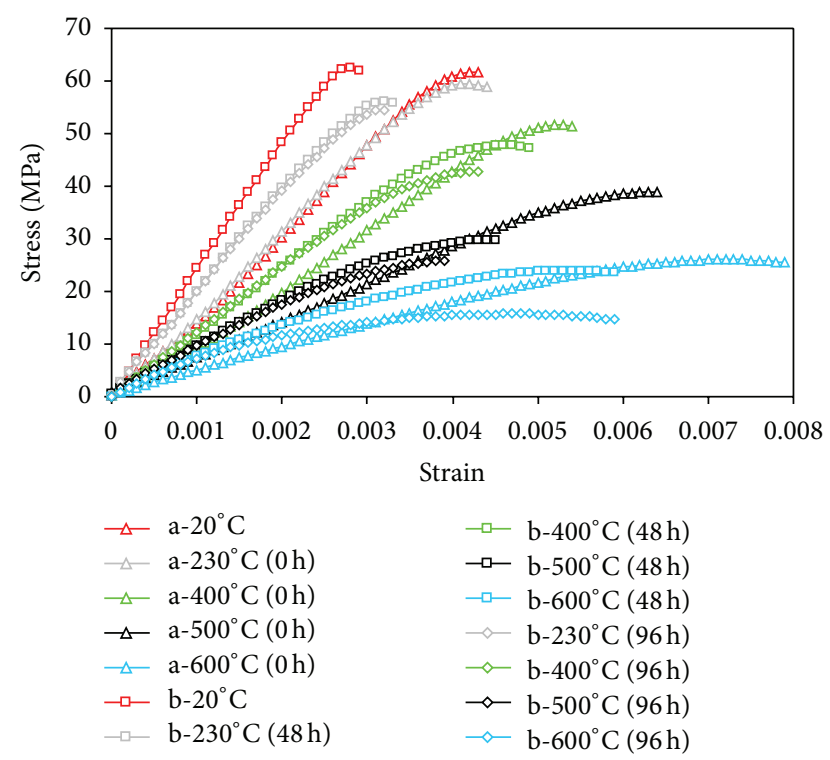

Figure 11: Comparison between residual stress-strain curves obtained after initial cooling-with specimen preloading.

Study results indicate that a substantial reduction of the compressive strength of the analyzed concrete mix develops during the first 96 hours after the initial cooling of the specimens. Further strength loss shows a tendency of slowing down as can be observed in Figure 12.

Figure 13 presents the impact of thermal exposure on the developed bond between cement and aggregate. With the increase of temperature exposure, bond dislocation [24] is more significant as can be seen in Figure 13. This effect is the cause of thermal cracking and the reduction of compressive strength and secant and dynamic modulus of elasticity. It should be noted that the further insight in understanding of

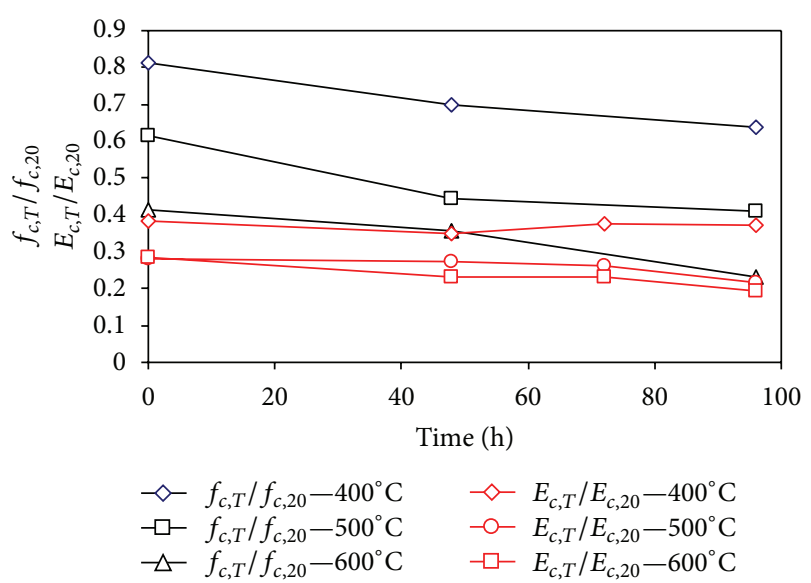

FIGURE 12: Time reduction of mechanical properties of concrete during 96 hours after initial cooling-(a).

the reduction of the mechanical properties after the initial cooling would be possible if more sophisticated equipment such as SEM (scanning electron microscope) was used. A much better resolution of the damaged bond between the cement paste and the aggregate could be achieved with this type of equipment. The SEM testing is certainly one of the directions for the future upgrading of the existent results and conclusions.

Furthermore, the effect of short-time reduction of compressive strength is not explicitly taken into account in engineering building codes $[13,17]$ and should be addressed in the future because of the observed magnitude of strength reduction. Given its significant measured value, the effect of short-term reduction of mechanical properties of concrete in real structures damaged by fire could have a significant effect on postfire load bearing capacity of the structure. In order to obtain a full insight into the basic parameters required for modelling the behaviour of prestressed hollow-core concrete structures after fire exposure, an additional research aiming at the determination of the maximum decrease of concrete strength and the level of strength recovery is necessary.

\section{Conclusions}

Considering the performed experimental and theoretical study, the following conclusions can be reached:

(i) the trend of residual compressive strength reduction of the analyzed concrete mix is quite similar to the trend of reduction of NSC, although the studied concrete has a compressive strength of about $72 \mathrm{MPa}$ after 28 days at ambient temperature;

(ii) distinct short-term reduction of compressive strength is observed in the first 96 hours after the initial cooling;

(iii) negligible short-term reduction of dynamic and secant modulus is observed during the first 96 hours indicating that values of both of the modulus appear to be unaffected by the chemical and physical changes that occur after the heating of concrete specimens. 


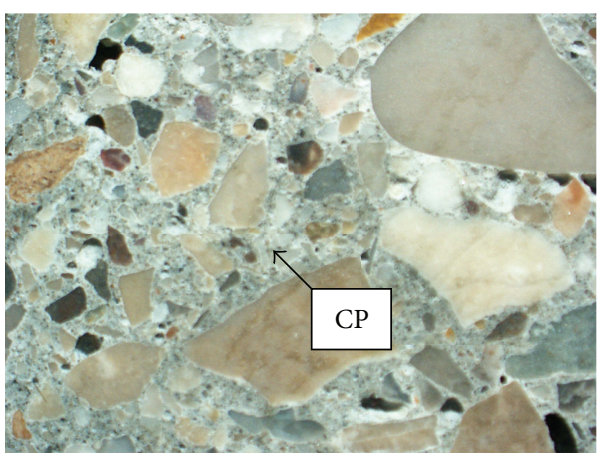

$20^{\circ} \mathrm{C}$

(a)

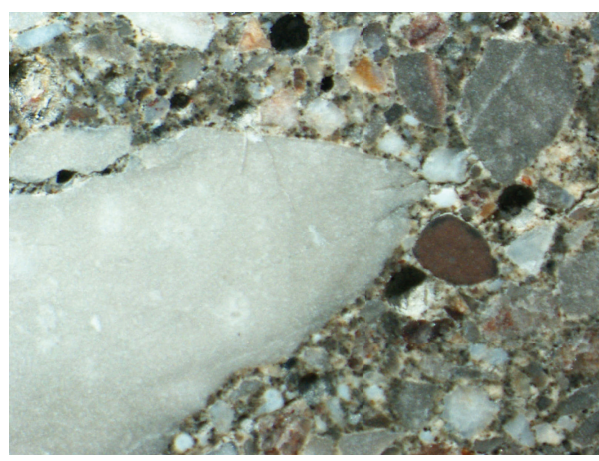

$500^{\circ} \mathrm{C}$

(c)

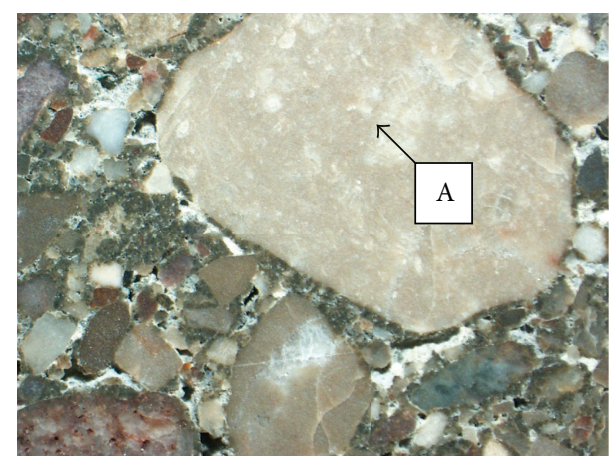

$400^{\circ} \mathrm{C}$

(b)

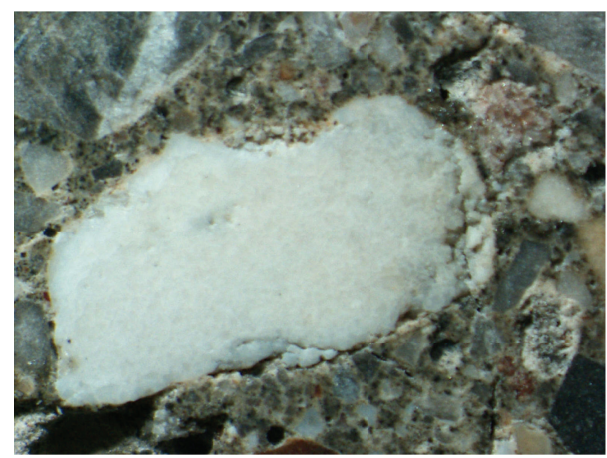

$600^{\circ} \mathrm{C}$

(d)

FIGURE 13: Impact of thermal action on cement-agregate matrix (Optical microscope). Notation: A: aggregate, CP: cement paste.

\section{Acknowledgments}

The research described in this paper was carried out within the Scientific Projects no. 083-0821466-1465 "Reliability of structures and risk assessment to extreme loading" and no. 083-0000000-1538 "Experimental and numerical research of earthquake resistance of structures" supported by the Ministry of Science, Education and Sport of the Republic of Croatia.

\section{References}

[1] G. L. Balázs and É. Lublóy, "Post-heating strength of fiberreinforced concrete," Fire Safety Journal, vol. 49, pp. 100-106, 2012.

[2] V. K. R. Kodur and L. Phan, "Critical factors governing the fire performance of high strength concrete systems," Fire Safety Journal, vol. 42, no. 6-7, pp. 482-488, 2007.

[3] R. Felicetti and P. G. Gambarova, "Expertise and assessment of materials and structures after fire," in FIB Bulletin 46: Fire Design of Concrete Structures-Structural Behaviour and Assessment, pp. 63-114, 2008.

[4] K. D. Hertz, "Concrete strength for fire safety design," Magazine of Concrete Research, vol. 57, no. 8, pp. 445-453, 2005.

[5] R. Felicetti and P. G. Gambarova, "Effects of high temperature on the residual compressive strength of high-strength siliceous concretes," ACI Materials Journal, vol. 95, no. 4, pp. 395-406, 1998.

[6] T. Harada, J. Takeda, S. Yamane, and F. Furumura, "Strength, elasticity and thermal properties of concrete subjected to elevated temperatures," ACI Concrete For Nuclear Reactor SP, vol. 34, pp. 377-406, 1972.

[7] Y.-H. Li and J. M. Franssen, "Test results and model for the residual compressive strength of concrete after a fire," Journal of Structural Fire Engineering, vol. 2, no. 1, pp. 29-44, 2011.

[8] J. A. Purkiss, Fire Safety Engineering Design of Structures, Butterworth-Heinemann, London, UK, 2007.

[9] M. A. Youssef and M. Moftah, "General stress-strain relationship for concrete at elevated temperatures," Engineering Structures, vol. 29, no. 10, pp. 2618-2634, 2007.

[10] RILEM TC 129 MHT, “Test methods for mechanical properties of concrete at high temperatures, part 5: modulus of elasticity of for service and accident conditions," Materials and Structures, vol. 33, pp. 219-223, 2000.

[11] RILEM TC 129 MHT, “Test methods for mechanical properties of concrete at high temperatures, part 3: compressive strength for service and accident conditions," Materials and Structures, vol. 28, no. 181, pp. 410-414, 1995.

[12] P. Bamonte and P. G. Gambarova, "A study on the mechanical properties of self-compacting concrete at high temperature and after cooling," Materials and Structures, vol. 45, no. 9, pp. 13751387, 2012. 
[13] EN1992-1-2:2004, Eurocode 2-Design of Concrete Structures-Part 1-2: General Rules-Structural Fire Design, European Committee for Standardization, Brussels, Belgium, 2004.

[14] L. T. Phan and N. J. Carino, "Code provisions for high strength concrete strength-temperature relationship at elevated temperatures," Materials and Structures, vol. 36, no. 256, pp. 91-98, 2003.

[15] M. Husem, "The effects of high temperature on compressive and flexural strengths of ordinary and high-performance concrete," Fire Safety Journal, vol. 41, no. 2, pp. 155-163, 2006.

[16] J. Xiao, M. Xie, and C. Zhang, "Residual compressive behaviour of pre-heated high-performance concrete with blast-furnaceslag," Fire Safety Journal, vol. 41, no. 2, pp. 91-98, 2006.

[17] EN1994-1-2:2005, Eurocode 4-Design of Composite Steel and Concrete Structures-Part 1-2: General Rules-Structural Fire Design, European Committee for Standardization, Brussels, Belgium, 2005.

[18] B. Chen, C. Li, and L. Chen, "Experimental study of mechanical properties of normal-strength concrete exposed to high temperatures at an early age," Fire Safety Journal, vol. 44, no. 7, pp. 997-1002, 2009.

[19] T. T. Lie, T. J. Rowe, and T. D. Lin, "Residual strength of fire exposed RC columns evaluation and repair of fire damage to concrete," American Concrete Institute SP, vol. 92, no. 9, pp. 153$174,1986$.

[20] A. Khennane and G. Baker, "Uniaxial model for concrete under variable temperature and stress," Journal of Engineering Mechanics, vol. 119, no. 8, pp. 1507-1525, 1993.

[21] Y. Anderberg and S. Thelandersson, "Stress and deformation characteristics of concrete at high temperatures 2. Experimental investigation and material behaviour model," Bulletin 54, Lund Institute of Tehnology, Lund, Sweden, 1976.

[22] A. M. Neville, Properties of Concrete, Prentice Hall, London, UK, 1995.

[23] L.-Y. Li and J. Purkiss, "Stress-strain constitutive equations of concrete material at elevated temperatures," Fire Safety Journal, vol. 40, no. 7, pp. 669-686, 2005.

[24] G. A. Khoury, "Effect of fire on concrete and concrete structures," Progress in Structural Engineering and Materials, vol. 2, no. 4, pp. 429-447, 2000. 

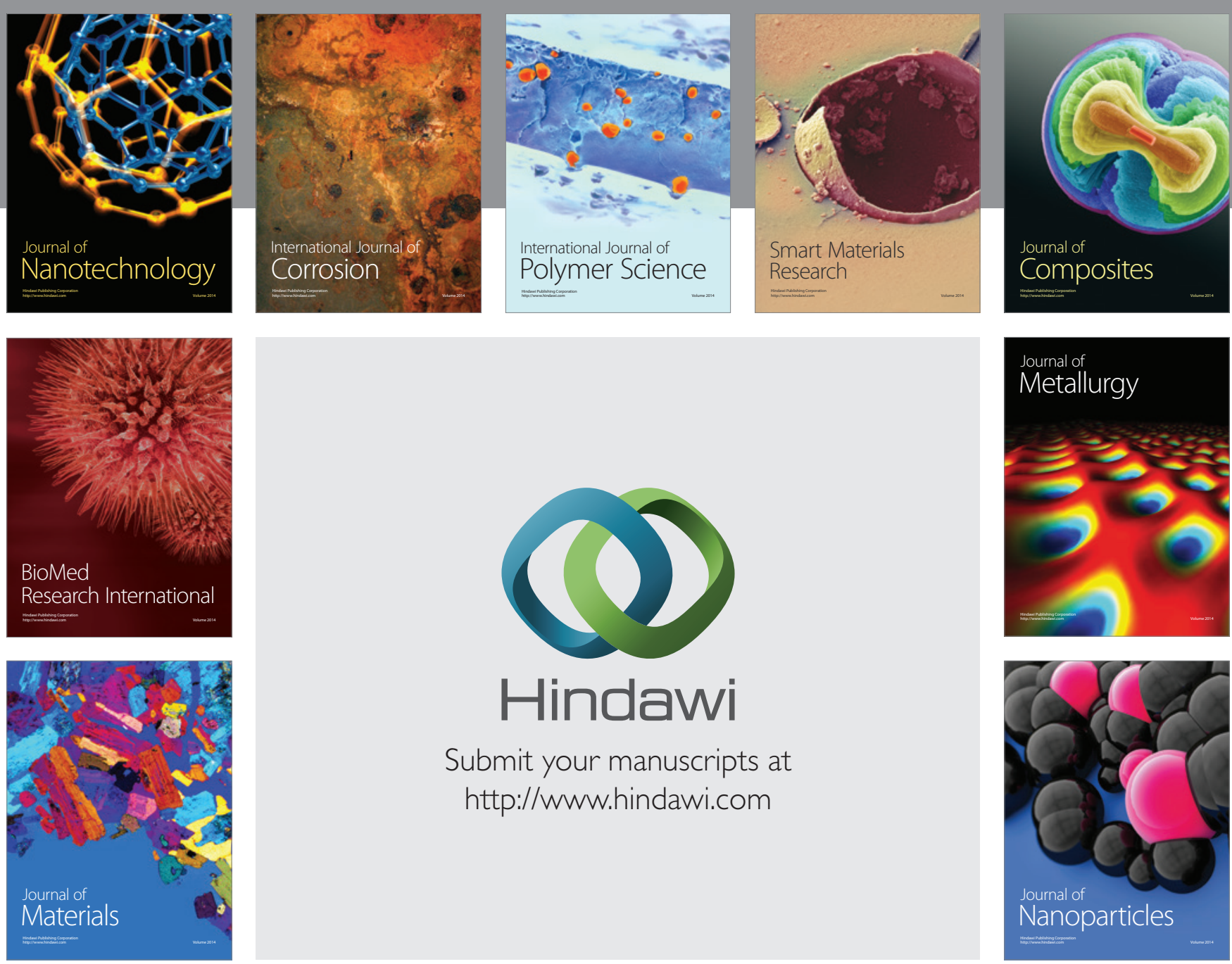

Submit your manuscripts at http://www.hindawi.com
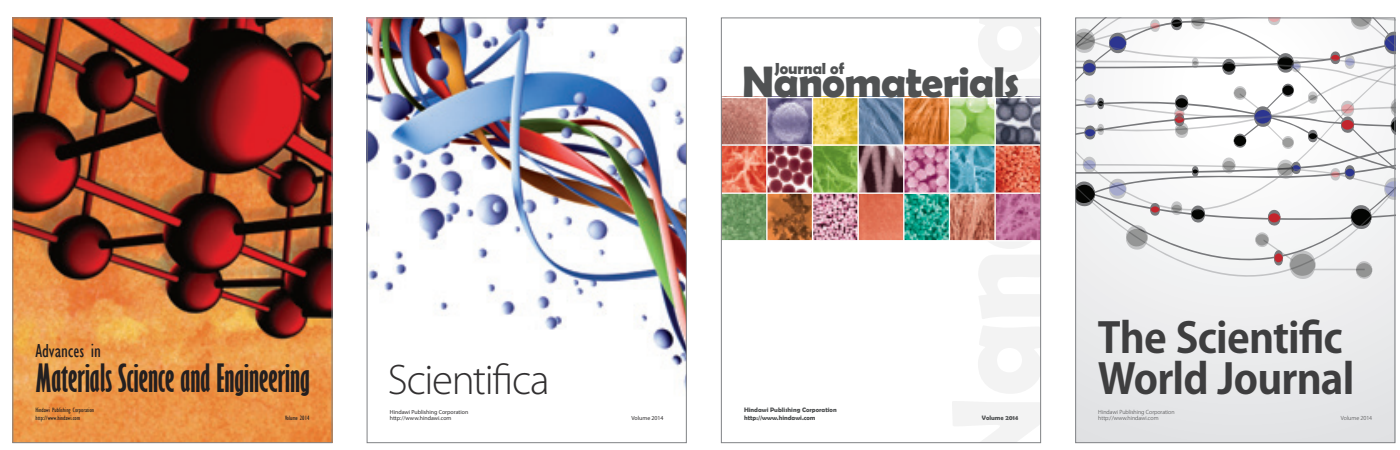

\section{The Scientific World Journal}
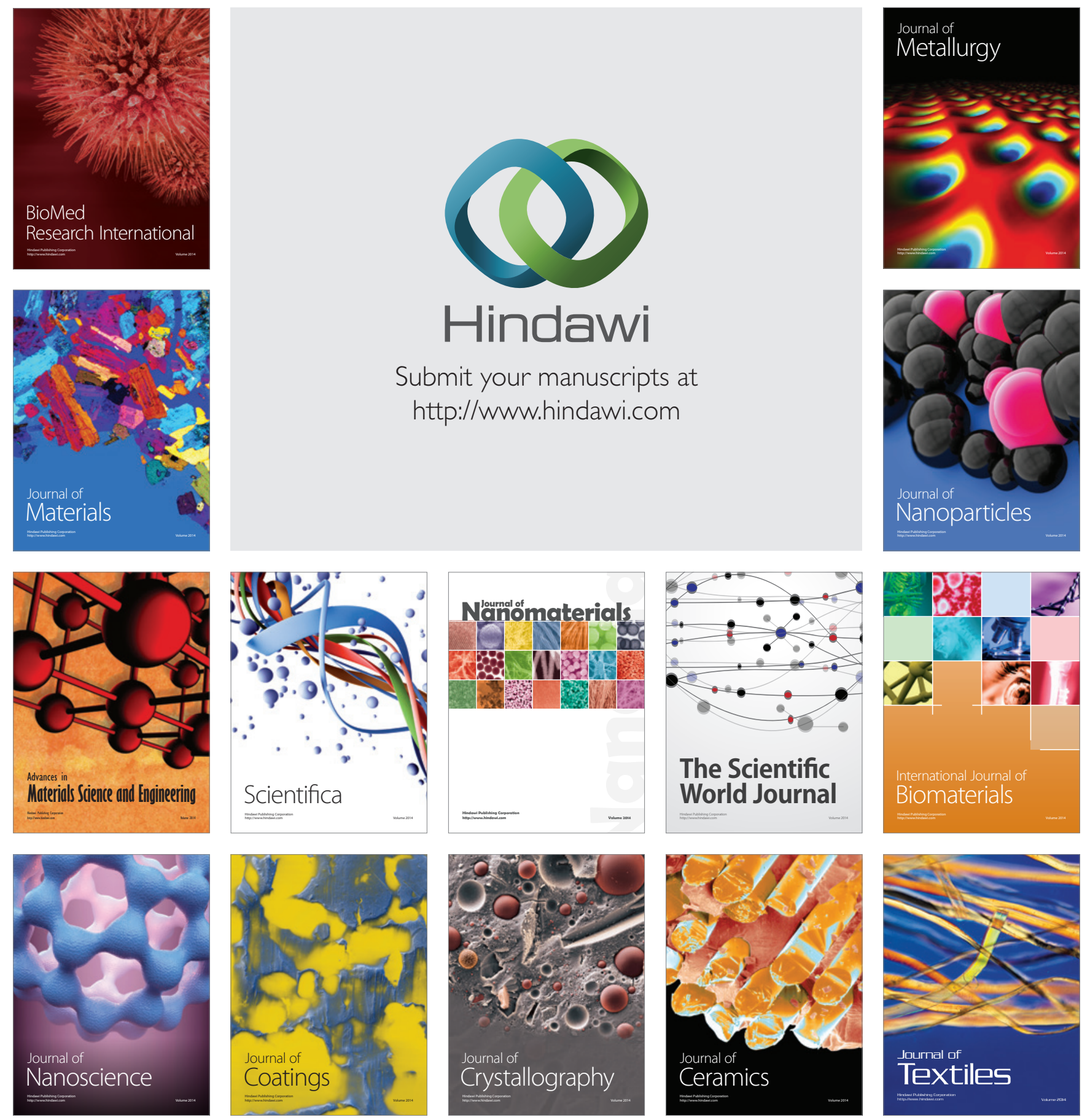